\title{
Isolation and Study of the Nutritional Variability of Peripheral Layers of Barley Grains During Development
}

\author{
Lahouaria Labga $^{1}$, Samira Meziani $^{{ }^{*}}$, Haoud Khadidja $^{1}$, Saidani Souad $^{1}$, Tasleem Tahir Aysha $^{2}$ \\ ${ }^{1}$ Department of Biology, Faculty of Life and Nature Sciences, Djillali Liabes University, Laboratory of \\ Biotoxicology, 12 Rue Oulhaci Mokhtar, Sidi Bel Abbes, Algeria \\ ${ }^{2}$ Department of Biosciences, Comsats University, Chak Shahzad Campus, Parkistan Road,
} Islamabad 45550

\begin{abstract}
Barley (Hordeum vulgare L.) is one of the grain cereals widely cultivated for human and animal consumption. The objective of this study was to determine the components of the peripheral layer (PL) of 4 stages of development of barley grain (Hordeum vulgare L.) (Saida 183) by manual isolation, as follows, $\mathrm{Mg}, \mathrm{Mn}$, and Ca content shows a progressive decrease through the development cycle from $(1.888 ; 0.0645 ; 8.345) \mathrm{mg} / \mathrm{l} \mathrm{DM}$ in ripening stage respectively, while Fe and $\mathrm{Zn}$ are increased in maturation stage $(0.663 ; 0.360) \mathrm{mg} / \mathrm{l}$ of $\mathrm{DM}$. The K content presented an important increase from $7.7 \mathrm{mg} / \mathrm{ml}$ in the maturity with a value of $30 \mathrm{mg} / \mathrm{ml}$. The average values of crude fiber content varied from 8.4 to 16.6. These values increase significantly with the development of the barley in different stages. The phytic acid content in the fourth stage (maturation) was $8.96 \pm 0.56 \mathrm{mg} / \mathrm{g} \mathrm{DM}$, and the proline content was very low in the first stage with a value of $(2.474 \pm 0.069) \mathrm{mg} / \mathrm{ml} \mathrm{DM}$ and in the maturation stage the value was high with a value of $(7.148 \pm 0.248) \mathrm{mg} / \mathrm{ml} \mathrm{DM}$. The optical observation of the different microstructures and progressive changes that were undergone from the first filling stage of the mid-milk stage, soft dough stage, physiological stage, and ripening stage were studied. By optical observation, there is the formation of the first protective envelope of the grain, so all the tissues of the external pericarp that is grouped with the testa. The aleurone layer was structured in three rows with an important condensation of the cells of the albumen sub-structures that are involved in the storage.
\end{abstract}

Keywords: Hordeum vulgare L.; peripheral layer; histological; grain development.

\section{Introduction}

In the region called the Fertile Crescent (now Iraq and Iran), the geographical origin of barley (Hordeum vulgare L.) can be traced back to several millennia before $\mathrm{J}-\mathrm{C}$. The world production of maize, wheat, rice, and barley reached more than $1148,765,755$, and 158 MT of cereal respectively [1]. Foods that have a cereal base are the main source of energy, protein, B vitamins, minerals and food for the current world population [2]. The use of grains has evolved considerably, and it is divided among human feed,

\footnotetext{
* Corresponding author: Meziani Samira, Email: meziani samira@yahoo.fr

(cc)) BY-NC-ND $@ 2022$ S. Meziani et al., published by De Gruyter Open. This work was licensed under the Creative Commons Attribution-NonCommercialNoDerivs 3.0 License
}

animal feed and non-food applications [3]. It is through structure and composition that the hardness of grains can be determined [4] and therefore, gives a capacity to the processing of grains in industrial food processes such as food manufacturing. There are two main types of barley, two-row and six-row of ears [5]. The main use of barley is for animal feed, in the form of barley meal or fodder; the barley is also used as a malting and brewing grain in the manufacture of beer and whisky [6]. In Algeria, the most important cereal is barley $(H$. vulgare L.). According to a survey of Polish households the cereal consumption provides $20-30 \%$ of the average intake of protein, thiamine, phosphorus and zinc, and $10-20 \%$ of many nutrients such as sodium, calcium, potassium, unsaturated fatty acids, niacin, riboflavin and vitamin B6 [7]. Barley grain 
has a complex material contains embryo which is responsible for vital activities of the grain. Dead cells filled with starch granules have a reserve of nutrient source (endosperm), testa and pericarp is semi-permeable membrane consisting of tubular cells, aleurone layer is 'a peripheral layer of cells contains proteins, lipids, vitamins, phytic acid and cellulose [8].

The most peripheral tissues (pericarp, testa) are little or not hydrolyzed by hydrolytic enzymes such as xylanases, unlike the aleurone layer [9]. The localization of substances is often performed by light microscopy to characterize the structure of cereal grains; on the other hand, the localization of other substances is most often performed using selective dyes, which reveal the distribution, for example: starch and polysaccharides [10]. For cereal grains there are no specified dyes for its staining, its localization requires immunolabeling or staining by Xylene Probe, which are more advanced and effective methods than direct staining [11]. Barley grains are mainly composed of carbohydrates (60 to $65 \%$ of the dry weight of barley) which are located mainly at the endosperm and $25 \%$ of amylose of linear structure, with bonds of type $\alpha$ (1-4) [12]. The protein content of barley grains is in the order of 10 to $17 \%[13,14]$ but there are also lipids in small amounts (2-3\%) [8,3]. Barley is characterized by the abundance of glutamic acid and proline, major characteristics of prolamins. It is a good source of minerals (such as Potassium, Phosphorus, and Magnesium). These minerals from grains can contribute significantly to the intake in the feed ratio [3]. The main objective of this study illustrated the structural distribution of the components in the cells of the endosperm and aleurone of the developing barley, based on the optical microscopic observation; analyze the gross chemical composition, and mineral composition.

\section{Material and Methods}

\section{Biological material}

The plant material used in this experiment is a line of barley (Hordeum vulgare L.) of the variety with Saida 183 in full development and the grains were sown on $07 / 11 / 2019$. Saida 183 is local barley with 6 rows, semi-late, with medium and hollow straw, medium tillering, good productivity $[15,16]$. The experiment was carried out at the level of the national institute of large-scale crops (ITGC) of Sidi Bel Abbes, Algeria. The peripheral layers are obtained after manually separating the bran from the grain.
Table 1. Agronomic, morphological, cultural and Qualitative characteristics of the tested varieties [16]

\begin{tabular}{ll}
\hline Saïda $\mathbf{1 8 3}$ & Characteristics \\
\hline Origin & Algeria (local) \\
\hline Morphological characteristic & Morphological characteristic \\
- Characteristic of the ear & Very loose \\
- Color of the spike & White \\
Height of the plant at maturity & 90cm \\
\hline Cultural characteristic & Cultural characteristic \\
Alternative & Fall \\
- Vegetative cycle & Semi-early \\
- $\quad$ Tallage & Medium \\
- Cultural characteristic & Cultural characteristic \\
To cold & Resistant \\
To lodging & Sensitive \\
To drought & Resistant \\
Qualitative characteristic & High 1,4\% \\
- Thousand kernel weight & \\
(TKW) &
\end{tabular}

\section{Plant sample preparation}

Grain detection was done with magnifying binocular magnifier (ZEISS, Germany) according to each stage of development, the endosperm powder obtained is not considered in this study (they will be the subject of further work). The peripheral layers of each phase as well as the endosperm powder were stored at $\left(-80^{\circ} \mathrm{C}\right)$ until analysis.

The samples were prepared and observed by the light microscopy method according to Nougaréde (1969) [17], we used the grains of each phase of development of barley in two extractions, then stored in $70 \%$ ethanol at $4{ }^{\circ} \mathrm{C}$ until the day of use, having followed the method that requires several steps to allow good observation by light microscopy. The fixation was made by formaldehyde to $36.99 \%$ that was used in different water baths after using melted kerosene to $56{ }^{\circ} \mathrm{C}$ until solidification, after passing in microtome for a very fine section of 4 to $5 \mu \mathrm{m}$, passing in dewaxing with toluene and dehydration by alcohol baths of decreasing degree (ethanol 100, 95, 70), finalized by a distilled water bath. The staining with toluidine blue requires important steps to realize the mounting and the observation by optical microscopy.

\section{Extraction and determination of phytate}

The phytic acid content was determined by the colorimetric method with a slight modification, using sulfosalicylic acid with a colored complex formation $[18,19]$. The extraction was performed by using $150 \mathrm{mg}$ of each sample which was mixed with $5 \mathrm{ml}$ of $2.4 \% \mathrm{HCL}$ in each tube, left in the dark for $2 \mathrm{~h}$ under orbital shaking every $10 \mathrm{~min}$ for 
15 sec using a vortex, after the solution was centrifuged $30 \mathrm{~min}$ at $6000 \mathrm{rpm}$ at $20^{\circ} \mathrm{C}$. At the end of $2 \mathrm{~h}$ a part of supernatant of $200 \mu \mathrm{l}$ was diluted 25 times in the test tubes with $4,8 \mathrm{ml}$ of distilled water by stirring the tubes during 5 seconds. By taking $750 \mu \mathrm{l}$ of dilution 1/25 (the standard range) were mixed with $250 \mu$ of Wade's rose solution (Wade's rose, HCL 2.4\%) mixed vigorously in a vortex mixer and centrifuged at $10000 \mathrm{rpm}$ at $20{ }^{\circ} \mathrm{C}$ during $20 \mathrm{~min}$, the absorbance was read at $500 \mathrm{~nm}$ on a spectrophotometer and the results were expressed in $\mathrm{mg} / \mathrm{g}$ for the quantity of phytic acid, all the tests were carried out in triplicate.

\section{Determination of the minerals contents}

The $\mathrm{Na}, \mathrm{K}, \mathrm{Mg}, \mathrm{Ca}, \mathrm{Zn}, \mathrm{Mn}$, and Fe content was assayed according to Rodier (2005) [20]. Mineralization that prepared from a stock solution of $100 \mathrm{mg} / \mathrm{l}$ for each phase of development of successive barley grain peripheral layer with $37 \%$ hydrochloric acid, nitric acid $69 \%$ and completed with distilled water. In 'to weigh $0,5 \mathrm{mg}$ of each sample prepared for testing after drying and grinding into a very fine powder in a $50 \mathrm{ml}$ beaker, to avoid any contamination the glass equipment was cleaned with distilled water and dried in an oven after each use. A standar 0, $45 \mu \mathrm{m}$ filter paper and an adjustable $1 \mathrm{ml}$ micropipette were used; aqueous solutions of reagents and standards were prepared using ultrapure water. The concentrations of heavy metals in the peripheral layers of barley were determined by atomic absorption spectrophotometry (AAS) with flame (AA-7000 SHIMADZU), the quantification of trace metals was performed with flame spectrometry (Jenway).

\section{Determination of crude fibers}

The determination of crude fiber was done according to Ween AOAC (1993) [21] in samples dried in an oven at $105-110^{\circ} \mathrm{C}$ for a few hours. A 1 $\mathrm{g}$ portion of the sample was ground with a Moulinex to obtain a fine powder that was collected by sieving to $1 \mathrm{~mm}$, then was placed in a glass crucible with glass frit bottom (ref; 11:1140, VELP SCIENTIFICA s.r.I, Via Stazione, 16USMATE (MI) Italy) $1,25 \%$ sulfuric acid to the $150 \mathrm{ml}$ mark and 3-5 drops of $\mathrm{N}$ - octanol as an anti-foaming agent were added. The samples were boiled for 30 minutes, the sulfuric acid was drained off, and the solid samples were washed three times with $30 \mathrm{~mL}$ of hot distilled water. After the last wash, $150 \mathrm{ml}$ of preheated $1.25 \%$ potassium hydroxide $(\mathrm{KOH})$ and 3-5 drops of the antifoaming agent were added. The filtrates were boiled for 30 minutes. The contents of the crucible were washed three times with $25 \mathrm{ml}$ of acetone.
Dry weight was determined after drying in an oven at $105^{\circ} \mathrm{C}$ for one hour and cooling in a desiccator. The ash content was determined after combustion for $4 \mathrm{~h}$ at $550{ }^{\circ} \mathrm{C}$ in a high temperature furnace after cooling for $1 \mathrm{~h}$ in a desiccator and the residue was weighed, the gross content is calculated as follows:

$\%$ in fiber $=[(\mathrm{F} 1-\mathrm{F} 2) \backslash \mathrm{F} 0)] \times 100$

where:

F0: weight of the dry sample

F1: weight of the crucible with residue

F2: weight of crucible with residue near ash

\section{Determination of proline}

Among the twenty main amino acids that enter the constitution of proteins is the pyrrolydine 2carboxylic acid or proline. The proline extraction was carried out according to the method described by [22] simplified and developed by [23]. $0,1 \mathrm{~g}$ of dried and grounded plant material was taken and placed in test tubes, to which $2 \mathrm{ml}$ of $40 \%$ methanol was added. The samples were heated in a water bath at $85{ }^{\circ} \mathrm{C}$, for 1 hour and after cooling, $1 \mathrm{ml}$ of each extract was taken. To each sample tube $1 \mathrm{ml}$ of acetic acid and $1 \mathrm{ml}$ of reagent prepared from $120 \mathrm{ml}$ distilled water, 300 $\mathrm{ml}$ acetic acid, $80 \mathrm{ml}$ orthophosphoric acid and 25 mg ninhydrin were added. The whole was boiled in a water bath at $100{ }^{\circ} \mathrm{C}$ for 30 minutes, after cooling; $5 \mathrm{ml}$ of toluene was added. After vigorous stirring, two phases were observed, the upper phase containing proline was removed and the lower aqueous phase without proline was eliminated, the phase containing proline was dehydrated by adding sodium sulfate $\left(\mathrm{Na}_{2} \mathrm{SO}_{4}\right)$. The final, colored solution was determined was determined spectrofotometricaly at $538 \mathrm{~nm}$; the values obtained were converted into proline content, the standard curve was stablished from a series of solutions of known proline concentration.

\section{Statistical analysis}

To compare the relationship between micronutrients in developing barley grains, all the results were obtained in three replicates, and they are expressed as mean \pm standard deviation (means plus or minus standard deviation as well as representations) and all the parameters were submitted to an analysis of variance (one factor) with the statistical software EXCEL 2010.

\section{Results and Discussion}

The microstructure of the developing barley grains was revealed by optical microscopy (Figure 1) using toluidine blue as a specific dye. Observing the cross-section of these four barley grain stages 
(Saida 183), the major part of the barley grain was constituted from the outside to the inside. Different tissues were distinguished in the whole of the external layers, first the envelope or testa surrounded by the internal and external pericarp, it constitutes the first protective envelope of the grain then the layer of aleurone with two to three rows of cells. In barley grains, the outer layers were separated into two composite layers, the first layer consisted of the whole pericarp and testa. The residues of the unicellular epidermis and aleurone were isolated as the second layer.

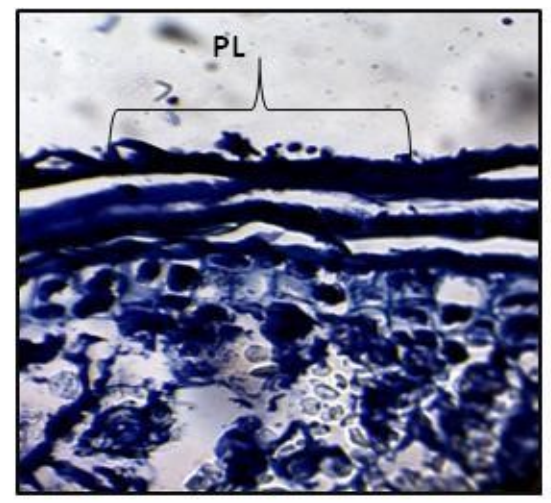

Stage 1

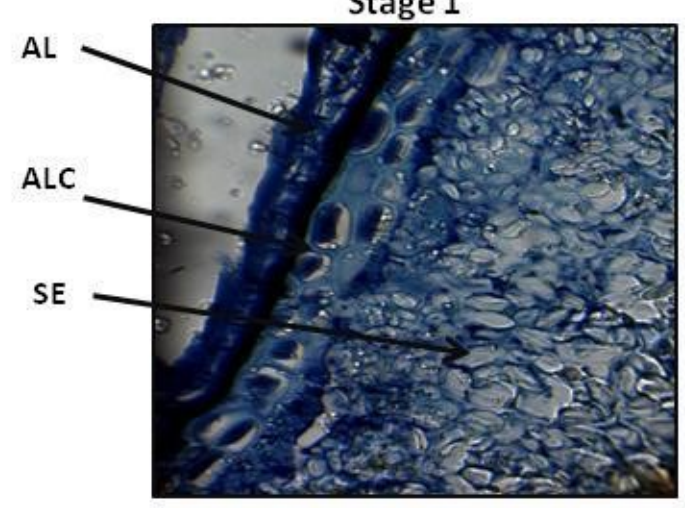

Stage 3

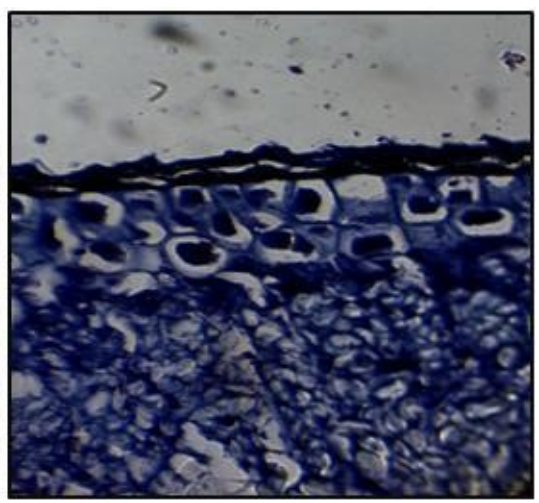

Stage 2

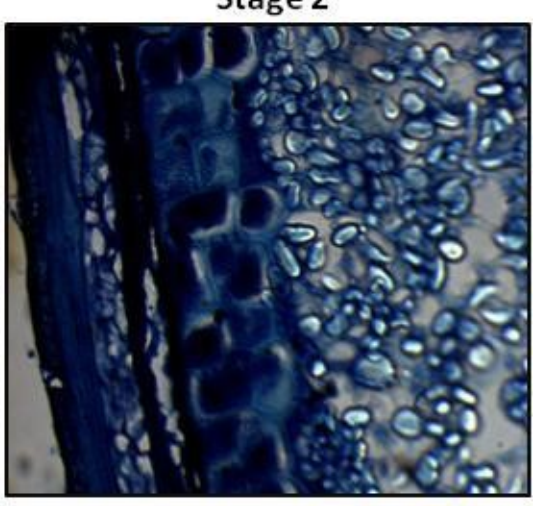

Stage 4

Figure 1. Cross section of barley grain at each stage of development observed under an optical microscope (magnification $\mathrm{x}$ ). (The soft barley grain allowed obtaining a composite layer of pericarp, testa, aleurone and endosperm: the sections are stained with toluidine blue). Stage 1: semi milky; stage 2: Soft dough; Stage 3: Physiological maturation; Stage 4: Maturation. Structural composition:

PL: Peripheral Layer; AL: Aleurone Layer; ALC: Aleurone Layer Cells; SE: Starchy Endosperm

At the first stage (mid-milk), it was observed he absence of the envelope of the fruit (pericarp), and the presence of testa which is a little separated from the hyaline band, entered in the interior there is the formation of the layer aleurone and of some cells of albumen. For the second stage (soft paste) there is the beginning of the the formation of the external envelope (pericarp) that is attached to the testa with the formation of a layer of aleurone and cells of albumen. Arriving at the third stage (physiological maturation) where there is the appearance of the external envelope, the testa, the layer of aleurone and the cells of the albumen are well condensed. In the fourth stage (maturation) we observed he formation of all the tissues of the seed, the external pericarp which is the first protective envelope of the grain, which is grouped with the testa. The aleurone layer was presented in three rows and an important condensation of the cells of the albumen.

Slight differences were observed in barley grain samples according to [24] barley tissues did not separate in the same way as wheat, even though the dissection procedure was similar. Although the exact location of the outer pericarp, which was crushed during grain development [25], was not easy to detect in the dissected layers in barley cultivars, its presence or absence could not explain this low amount. It could rather be related to the type of barley (a2rangs), since all these characteristics tend to reduce the proportion in the barley grain [26]. The relative proportion of the 
aleurone layer in the whole outer layer was higher in barley grain than wheat grain where the value was about $45 \%[24,26]$. This could be related to the relative thinness of the other tissues of the maternal barley grain, the amount of aleurone layer in the barley grain being comparable to that of wheat grain [24].

\section{Phytic acid}

The results of phytate content show that all stages of development of barley grains, which contain phytate have varying amounts from one stage to another in increasing order ranging from 5.22 to $8.96 \mathrm{mg} / \mathrm{g}$. The phytate content of the peripheral layers of the four stages of developing barley grain wasermined. Stage one (mid-milk) has the lowest phytate content with $5.22 \pm 0.267 \mathrm{mg} / \mathrm{g}$ $\mathrm{DM}$, this value starts to increase in the second phase (soft dough) with $6.22 \pm 0.166 \mathrm{mg} / \mathrm{g}$ DM until stage three (physiological ripening) with 7.57 $\pm 0.120 \mathrm{mg} / \mathrm{g} \mathrm{DM}$, stage four (ripening) the phytate content has $8.96 \pm 0.56 \mathrm{mg} / \mathrm{g} \mathrm{DM}$. Figure 2 shows the phytate content of barley grains Saida183 in development.

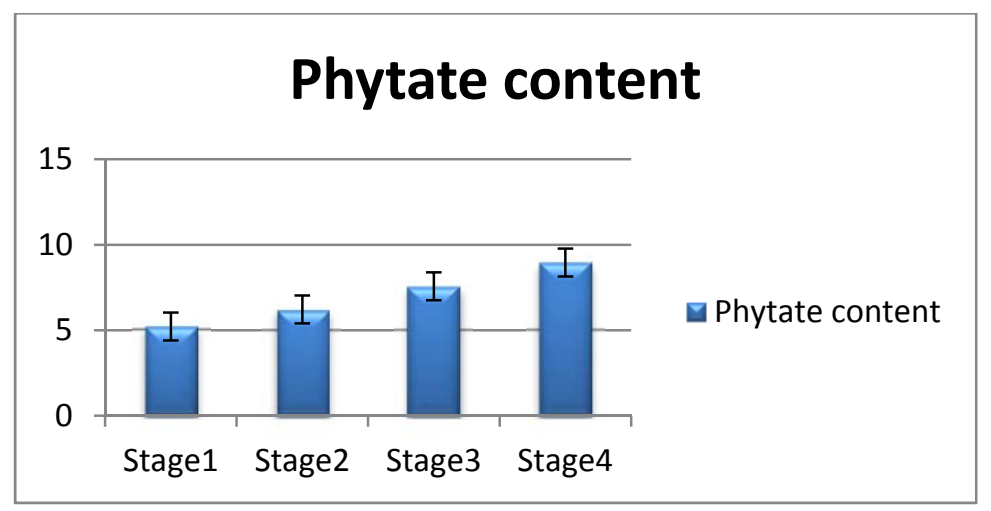

Figure 2. Phytic acid content of barley grain (Saida 183) in full development. Stage 1: semi milky; stage 2: Soft dough; Stage 3: Physiological maturation; Stage 4: Maturation.

Phytic acid is a molecule of plant origin that plays the main role in storing phosphorus in plant tissues. Phytic acid synthesis is procured in developing grains $[27,28]$, it plays a role in the vegetative cycle to prevent very early germination and is a natural defense against grain predators, releasing large amounts of phosphorus for energy production [29]. Phytic acid is mainly stored in the aleurone layer (about $80 \%$ ) or germ [30,31]. According to Schlemmer et al. (2009) [31] the phytic acid content between (3.8 and 11.6) $\mathrm{mg} / \mathrm{g}$ DM is comparable to that obtained by our variety, these values are of the same order of magnitude as those observed for barley [32] or wheat [33]. The study from $[34,35]$ contacted the values generally ranging from 1.42 to $20.70 \mathrm{mg} / \mathrm{g}$.

The analysis of variance shows that the phases in the development of barley grain from milky phase to maturity have significant effects $(p<0.05)$ on phytic acid content. These values have deprived to the half, we explain these results by the endogenous phytase activity synthesized during the germination period which continues the bioavailability during the whole vegetative cycle, but hydrolysis develops slowly and the difference of reduction differs from one species to another of cereal rye $>$ wheat $>$ barley $>$ corn $[36,37]$. Some researchers stated that the phytase activity of cereals in the native state is influenced by cultivar, climatic conditions like heat and humidity. This phytase activity has recorded a high content for rye grains and the lowest is proven for corn grain $[38,39]$

\section{Mineral composition}

The measured mineral content of the peripheral layers of the different developmental stages of barley grains (Saida183) and the differences in the concentrations of the metallic trace elements was calculated relative to the dry weight of the extract of the peripheral layer and are expressed in $\mathrm{mg} / \mathrm{ml}$ per $100 \mathrm{~g}$ of DM for the $\mathrm{Na}$ and $\mathrm{K}$ and in $\mathrm{mg} / \mathrm{l}$ per $1000 \mathrm{~g}$ (ppm) for $\mathrm{Mn}, \mathrm{Fe}, \mathrm{Zn}, \mathrm{Ca}$ and $\mathrm{Mg}$ are shown in Table 2. 
Table2. Mineral content of barley grain (Saida 183) in full development in $\mathrm{mg} / \mathrm{ml}$ ( $\mathrm{Na}$ and $\mathrm{K}$ ) and $\mathrm{mg} / \mathrm{l}$ (Mn, Fe, Zn, Ca and Mg)

\begin{tabular}{lcccc}
\hline Minerals & Stage 1 & Stage 2 & Stage 3 & Stage 4 \\
\hline $\mathrm{K}$ & $7.7 \pm 0.424$ & $10.5 \pm 0.707$ & $13.9 \pm 0.141$ & $30 \pm 1.414$ \\
\hline $\mathrm{Na}$ & $18.75 \pm 0.353$ & $22 \pm 0.141$ & $24.5 \pm 0.707$ & $10.6 \pm 1.272$ \\
\hline $\mathrm{Mn}$ & $0.0645 \pm 0.0006$ & $0.023 \pm 0.0019$ & $0.022 \pm 0.005$ & $0.021 \pm 0.001$ \\
\hline $\mathrm{Fe}$ & $0.550 \pm 0.028$ & $0.342 \pm 0.003$ & $0.458 \pm 0.004$ & $0.663 \pm 0.002$ \\
\hline $\mathbf{Z n}$ & $0.691 \pm 0.003$ & $0.037 \pm 0.001$ & $0.042 \pm 0.005$ & $0.360 \pm 0.004$ \\
\hline $\mathbf{C a}$ & $8.345 \pm 0.002$ & $2.763 \pm 0.006$ & $2.717 \pm 0.002$ & $1.355 \pm 0.007$ \\
\hline $\mathbf{M g}$ & $1.888 \pm 0.001$ & $1.737 \pm 0.016$ & $1.728 \pm 0.006$ & $1.626 \pm 0.017$ \\
\hline
\end{tabular}

The analysis of variance revealed that the contents of $(\mathrm{Na}),(\mathrm{Mn}, \mathrm{Fe}$, and $\mathrm{Mg}),(0.00066)$ $\mathrm{mg} / \mathrm{ml},(0.0014 ; 0.0001 ; 0.00022) \mathrm{mg} / \mathrm{l}$ of DM are respectively significant, while the contents of $(K)$,
(Ca, and Zn), (3.7912) mg/ml, (7.287; 2.2099) $\mathrm{mg} / \mathrm{l}$ of DM, there is not significant difference at the $5 \%$ risk of error across the different phases of development (Figure 3).

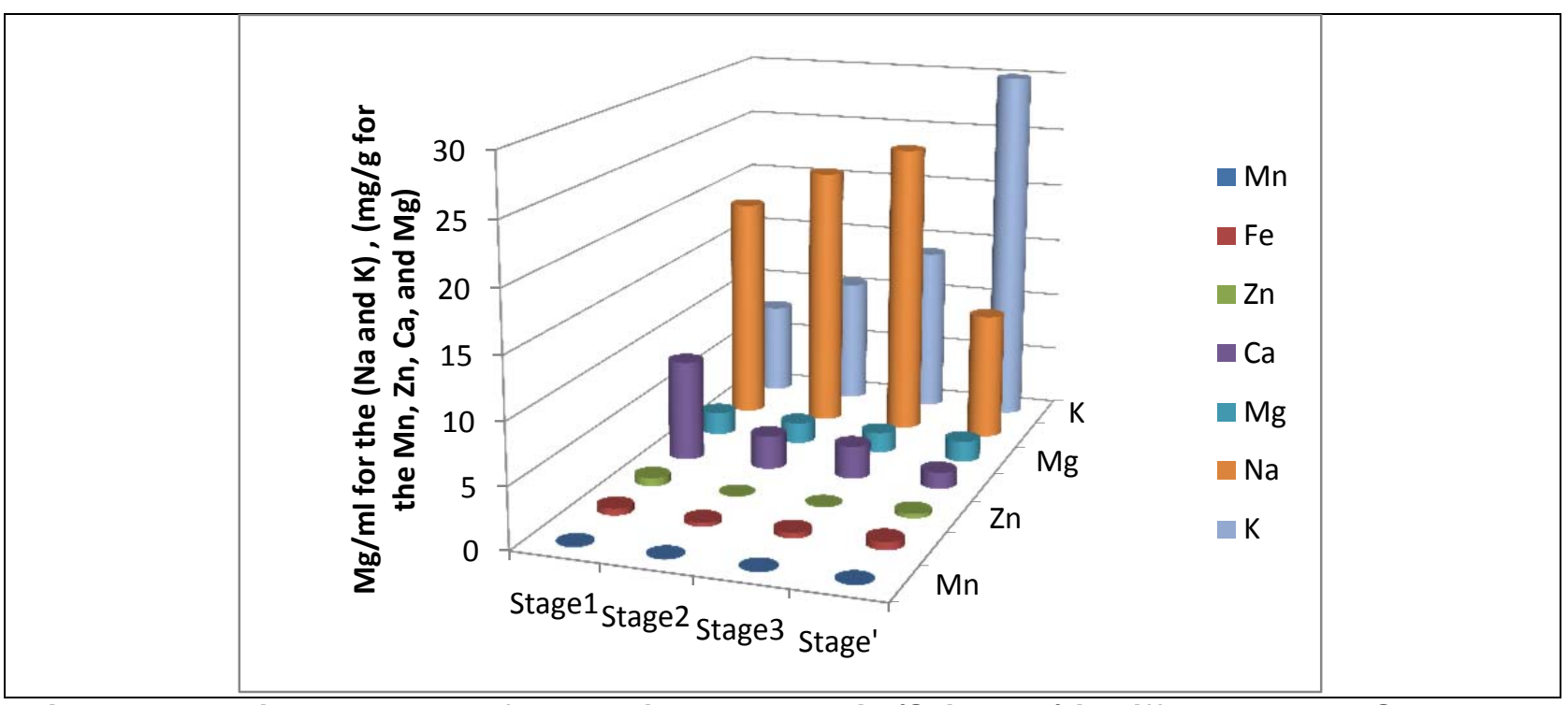

Figure3. The mineral content of developing barley grain (Saida 183) in different stages. Stage 1: semi milky; stage 2: Soft dough; Stage 3: Physiological maturation; Stage 4: Maturation. The results for the different metals are significantly different

The content of $\mathrm{Mg}, \mathrm{Mn}$ and $\mathrm{Ca}$ presents a progressive decrease through the development cycle from $(1.888 ; 0.0645 ; 8.345) \mathrm{mg} / \mathrm{l} \mathrm{DM}$ in midmilk stage to $(1.626 ; 0.021 ; 1.355) \mathrm{mg} / \mathrm{l} \mathrm{DM}$ at the maturation stage respectively, while $\mathrm{Fe}$ and $\mathrm{Zn}$ in the midmilk stage presents a value of $(0.550$; $0.691) \mathrm{mg} / \mathrm{l} \mathrm{DM}$ after it starts to decrease until the maturation stage which increased to $(0.663$; $0.360) \mathrm{mg} / \mathrm{l} \mathrm{DM}$. For $\mathrm{Na}$ in phase 1 presents a value of $(18.75) \mathrm{mg} / \mathrm{ml}$ or it begins to increase in phase 2 and phase 3 with values of (22 and 24.5) $\mathrm{mg} / \mathrm{ml}$ respectively, arrived at phase 4 it decreased until (10.6) $\mathrm{mg} / \mathrm{ml}$. The potassium (K) presents an important increase from $(7.7) \mathrm{mg} / \mathrm{ml}$ at phase 1 until phase 4 with a value of $30 \mathrm{mg} / \mathrm{ml}$. Natural metal elements are essential substances for our organism which are indispensable for the proper functioning of the organism. They are present in very small quantities in the form of traces in non-excessive concentrations. Minerals are present in small quantities in barley grain and the main ones are potassium, manganese and copper often associated with salts (phosphates, chlorides or sulphate) [40]. The peripheral layers include a living cell tissue rich in minerals providing about $40 \%$ of the minerals of the grain, phosphorus (phytate), potassium, magnesium, zinc and iron [41- 44]. A decrease in certain metals such as the results found in this study more particularly at the level of $\mathrm{Mg}, \mathrm{Mn}$ and $\mathrm{Ca}$ and also on the value of Zinc for different stages, indicates that there is a probability that phytic acid which one of the primary causes of mineral decrease according to a study by $[45,46]$ have 
also shown that the minerals in barley grain are found in sufficient concentration to meet the nutrient requirement of the seedling. the most abundant in barley grains [47], metals like (Fe, $\mathrm{Zn}$, $\mathrm{Ca}, \mathrm{Na}, \mathrm{Mn}, \mathrm{Mg}$ ) plays an important role in the biological system [48]. A great variability in mineral content from one sample of the peripheral layer to another has been highlighted in the literature, these differences are under the influence of environmental factors that characterize the grain culture and the varietal effect $[49,50]$. Magnesium is also localized in the bran and a aleurone layer which is required for photosynthesis in the peripheral layers during the first 30 days of grain formation and accumulation and a mineral deficiency of $\mathrm{Mg}$ in cereals reduces photosynthesis of several metabolic functions which leads to lower grain weight and weaker defenses against stress [51]. In barley grains, the peripheral layer is the primary storage site for phosphate, magnesium, potassium, sodium, and calcium, accumulating more than $70 \%(97 \%$ for magnesium) of the endosperm reserves of these minerals [52]. Iron plays an important role in the production of hemoglobin and red globin, insufficient iron intake results in anemia [53]. Zinc promotes normal growth and development during pregnancy, childhood and adolescence, affects the immune system, wound healing, and the senses of taste and smell [54]. Cereals are used as a staple food in developing countries, macromicronutrients are a good source for human nutrition or the human body is unable to produce them.

\section{The content of crude fiber and proline}

The crude fiber and proline contents of the different peripheral layers of developing barley grains (Saida 183) are presented in Table 3 and Figures $4 \mathrm{a}$ and $4 \mathrm{~b}$. The average values of crude fiber content varied from 8.4 to 16.6, these values increase significantly with the development of barley of different stages, which are presented by Figures 4.

According to our results has the phase of maturity is expressed at $16.6 \%$ this content is inferior to that [55] is estimated at $27.33 \%$ of DM, but it is close to the results reported by [56] which range from $18 \%$ to $24 \%$. Comparing the fiber content in other cereal species (millet, wheat, barley) [57] note that barley is the richest in fiber; its content is about $26 \%$ of DM. According to [58] that the peripheral tissues contain the major part of fiber and minerals, in fact, these tissues represent approximately $14 \%$ of the grain in mass contain $75 \%$ of the fibers present in the grain according to the histological origin, the structure and properties of the fibers vary. The grain is much richer in raw cellulose for barley, if the rate is more than $5 \%$, these elements form cell walls, and their energy inputs are relatively low because of their low digestibility. The wheat bran is richer in insoluble fiber than barley, on the other hand, it has been found that people who follow cereal-based diets such as wheat or barley have a beneficial physiological effect on the postprandial insulin response in obese humans who are at risk of insulin resistance [59, 60]. Products with new functional and nutritional properties are a prerequisite for better acceptance of barley, e.g. as high dietary fiber products [61, 62]. According to Biel et al. (2015) [63], barley grain dietary fiber (dietary fiber, TDF) contains $265 \mathrm{~g}$ in $\mathrm{Kg} \mathrm{DM}$, classified into soluble and insoluble fibers, based on their ability to dissolve in water, their ease of digestion by floral bacteria in the gut, and other chemical properties such as water retention.

Proline is a multifunctional amino acid; it is implicated in some processes of plant development such as germination and reproduction. According to the results obtained in the four stages, the accumulation of proline revealed a significantly difference at the level of $(p<1 \%)$ which is presented in Figure 5 . The proline content was very low in the first stage with a value of $(2.474 \pm 0.069) \mathrm{mg} / \mathrm{ml}$ of DM, through the two stages of development the proline content was $(4.624 \pm 0.307) \mathrm{mg} / \mathrm{ml}$ of $\mathrm{DM}$ for stage two, was $(4.8 \pm 0.19) \mathrm{mg} / \mathrm{ml}$ of DM for the third stage and in the maturation stage the value of proline was important with a value of $(7.148 \pm 0.248)$ $\mathrm{mg} / \mathrm{ml}$ of DM. Our results indicate that proline content increases significantly and highly significantly with temperature and plays a role in achieving ionic and osmotic equilibrium in the different developmental stages of barley grain (Saida 183). Proline accumulation is an important process for developing crop tolerance under adverse environmental conditions [67] and can be considered as an indicator of crop defense mechanism in response to multiple stresses or [68] concluded that proline accumulation increases under stress and optimizes grain yield, and [69] indicated that heat and water stress stimulated the concentration of proline and Osmo protector significantly. The study for [67] reported an unattainable concentration of proline under stress conditions in resistance genotypes. 
Table 3. Dietary fiber content expressed as percentage of dry matter (DM) and proline in $\mathrm{mg} / \mathrm{ml}$

\begin{tabular}{lllll}
\hline Stages & Stage1 & Stage 2 & Stage 3 & Stage 4 \\
\hline Crude fiber \% & 8.4 & 10.4 & 12.2 & 16.6 \\
\hline The level of proline $(\mathrm{mg} / \mathrm{ml})$ & $2.474 \pm 0.069$ & $4.624 \pm 0.307$ & $4.8 \pm 0.19$ & $7.148 \pm 0.248$
\end{tabular}

Stage 1: semi milky; stage 2: Soft dough; Stage 3: Physiological maturation; Stage 4: Maturation.

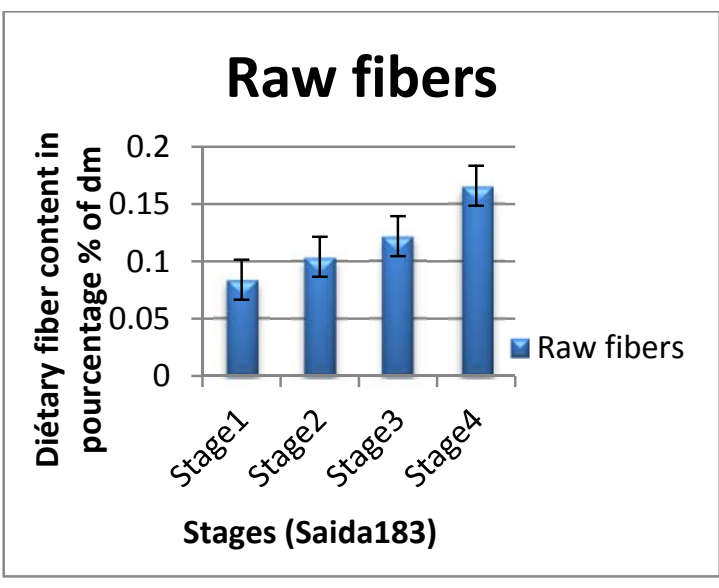

a

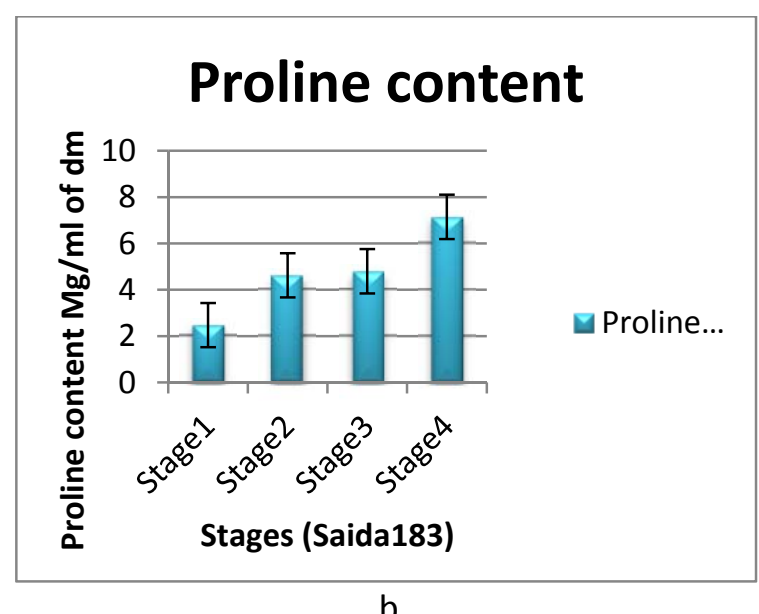

b

Figure 4. The Fiber content and the proline content of the four of developing barley grain (Saida 183). Stage 1: semi milky; stage 2: Soft dough; Stage 3: Physiological maturation; Stage 4: Maturation.

\section{Conclusions}

For thousands of years, mankind has been feeding on cereal grains, which are considered a good source of food. The microstructure of the developing barley grain presents that it is a good source of micronutrients especially fiber, proline, and minerals with its constitution in three rows of aleurone layer. According to the present results, the peripheral layers of the developing barley grain is an important source of minerals, fiber, phytate, and proline at different stages of development, this can be related to the environmental conditions, the richness of the soil in heavy metals, the variety of barley used, and the extraction solvent. As a consequence, barley bran could be a good option to be introduced in daily food.

\section{References}

1. Faostat. (2019). Food and Agriculture Organization of the United Nation. http://www.fao.org/faostat/en/\#data2019

2. Monterrey, D. (2016). Cereals: Dietary Importance. Encyclopedia of Food and Health. Elsevier Ltd

3. Saulnier, L. (2012). Cereal Grains: Diversity and Nutritional Compositions. Cahier de Nutrition and Diététiques; 47, 54-515

4. Nair, S., Knoblauch, M., Ullrich, S., Baik, B.K. (2011). Microstructure of hard and soft kernels of barley. Journal of Cereal Science, 54 (3), 354-362 https://doi.org/10.1016/j.jcs.2011.06.014

5. Baik, B.K., Ullrich, S.E. (2008). Barley for food: characteristics, improvement, and renewed interest.
Journal of Cereal Science, 48, 233-242 https://doi.org/10.1016/j.jcs.2008.02.002

6. Edney, M.J. (2004). Mather DE. Quantitative trait loci affect in germination trait $s$ and malt friability in a two-rowed by six -rowed barley cross. Journal of Cereal Science, 39, 283-290 https://doi.org/10.1016/j.jcs.2003.10.008

7. Laskowski, W., Gorska-Warsewicz, H., Rejman, K., Czeczotko, M., Zwolinska, J. (2019). How important are cereals and cereal products in the average polish diet? Nutrients, 11(3), 679 https://doi.org/10.3390/nu11030679

8. Hariri, A. (2003). Study and modeling of malting tempering. Thesis of D. thesis. ENSIA, Institut national polytechnique of Lorraine, specialty: biotechnology and food industries. p. 218.

9. Ordaz-Ortiz, J.J., Devaux, M.F., Saulnier, L. (2005). Classification of wheat varieties based on structural features of arabinoxylans as revealed by endoxylanase treatment of flour and grain. Journal of Agricultural and Food Chemistry, 53, 8349-8356 https://doi.org/10.1021/jf050755v

10. Dornez, E., Cuyvers, S., Holopainen, U., Nordlund, E., Poutanen, K., Delcour, J.A., Courtin, C.M. (2011). Inactive fluorescently labelled xylanase as a novel probe for microscopic analysis of arabinoxylan containing wheat cell walls. Journal of Agricultural and Food Chemistry, 59, 6369e6375 https://doi.org/10.1021/jf200746g

11. Guillon, F., Tranquet, O., Quillien, L., Utille, J.P., Ordaz, Ortiz, J.J., Saulnier, L. (2004). Generation of polyclonal and monoclonal antibodies against arabinoxylans and their use for immunocytochemical location of arabinoxylans in cell walls of Endosperm of wheat. Journal of Cereal Science, 40, 167e182 
12. Jilal, A. (2011). Assessment of genetically diverse international barley germplasm for development of food product applications. Thesis of doctora. Southern Cross University, p. 186

13. Czuchajowska, Z., Klamczynski, A., Paszczynska, B., Baik, B.K. (1998). Structure and functionality of barley starches. Cereal Chemistry, 75, 747-754

http://dx.doi.org/10.1094/CCHEM.1998.75.5.747

14. Izydorczyk, M.S., Storsley, J., Labossiere, D., MacGregor, A.W., Rossnagel, B.G. (2000). Variation in total and soluble b-glucan content in hulless barley: effects of thermal, physical, and enzymic treatments. Journal of Agricultural and Food Chemistry, 48, 982989. https://doi.org/10.1021/jf991102f

15. Boufena, Z., Zaghouane, O., Zaghouane, F. (2006). Guide to the main varieties of straw cereals in Algeria. Ed ITGC; ICARDA; Algiers $154 \mathrm{p}$

16. Guide of the main varieties of Straw cereal in Algeria, (2006).

17. Nougarède, A. (1969). Plant biology. Volume I. Cytology. Ed. Masson; 598p

18. Latta, M., Eskin, M. (1980). A Simple and Rapid Colorimetric Method for Phytate Determination. Journal of Agricultural and Food Chemistry, 28, 13131315. https://doi.org/10.1021/jf60232a049

19. Vaintraub, L.A., Lapteva, N.A. (1988). Colorimetric determination of phytate in unpurified extracts of seeds and the products of their processing. Analytical Biochemistry, 175, 227-230pp https://doi.org/10.1016/0003-2697(88)90382-X

20. Rodier, J. (2005). The water analysis "natural water, waste water, sea water" (Paris: Bordas, 1984).p 66.

21. Ween the AOAC. (1993). Methods of analysis for nutrition labeling. Airlington, USA. Fiber extractor for dosing of the raw fiber content; References 10521 \& 10522

22. Troll, W., Lindsley, J.A. (1955). Photometric method for determination of proline. Jornal of Biological Chemistry. $\quad 215, \quad 655 \quad-\quad 660$ https://doi.org/10.1016/S0021-9258(18)65988-5

23. Rasio, A., Sorrentinio, G., Cedola, M.C., Pastore, D., Wittner, G. (1987). Osmotic and elastic adjustment of durum wheat leaves under stress conditions. Genetic Agr; 41, p: $427-436$ https://doi.org/10.3923/ajbs.2020.119.126

24. Barron, C., Surget, A., Rouau, X. (2007). Relative amounts of tissues in mature wheat (Triticum aestivum L.) grain and their carbohydrate and phenolic acid composition. Journal of Cereal Science, 45 ,88-96 https://doi.org/10.1016/j.jcs.2006.07.004

25. Briggs, D.E. (1987). The morphology of barley; the vegetative phase, in: Briggs, D. E. (Ed. Eds), Barley. Chapman and Hall Ltd: London; 1-15

26.Evers, A.D., Blakeney, A.B., O'Brien, L. (1999). Cereal structure and composition. Australian Journal of Agricultural Research, 50, 629-650

27. Coban, H.b., Demirci, A. (2017). Chapter 2 Phytase as a diet ingredient: from microbial production to its applications in food and feed industry. In Microbial Production of Food Ingredients and Additives [online]. Academic Press. 33-55, Handbook of Food Bioengineering; ISBN978-0-12-811520-6
28. Kumar, V., Sinha, A. K., Makkarh, P.S., Becker, K. (2010). Dietary roles of phytate and phytase in human nutrition. Food Chemistry, 120 (4), 945-959. https://doi.org/10.1016/j.foodchem.2009.11.052

29. Selle, P.h., Ravindran, V. (2007). Microbial phytase in poultry nutrition. Animal Feed Science and Technology, $\quad 135 \quad$ (1), $1-41$ https://doi.org/10.1016/i.anifeedsci.2006.06.010

30. Kumar, V., Sinha, A.k. (2018). Chapter 3 -General aspects of phytases. In: Enzymes in Human and Animal Nutrition [online]. Academic Press. 53-72. ISBN978-0-12- 805419-2

31. Schlemmer, U., Frolich, W., Prieto, Rafel, M., Grases, F. (2009). Phytate in foods and significance for humans: food sources, intake, processing, bioavailability, protective role and analysis. Molecular Nutrition \& Food Research; 53 Suppl 2, S330-375 https://doi.org/10.1002/mnfr.200900099

32. Dai, F., Qiu, L., Xu, Y., Cai, S., Qiu, B., Zhang, G. (2010). Differences in phytase and phytic acid content between cultivated and tibetan annual wild barleys. Journal of Agricultural and Food Chemistry; 58, 1182111824 https://doi.org/10.1021/jf1029948

33. Barron, C., Samson, M. F., Lullien-Pellerin, V., Rouau, X. (2011). Wheat grain tissue proportions in milling fractions using biochemical marker measurements: application to different wheat cultivars. Journal of Cereal Science; 53, 306-311 https://doi.org/10.1016/j.jcs.2011.01.013

34. Tang, A. L., Wilcox, G., Walker, K. Z., Shah, N. P., Ashton, J. F., Stojanovsk, A. (2010a). Phytase activity from Lactobacillus spp. in calcium-fortified soymilk. Journal of Food Science. 75, 6, M373-M376 https://doi.org/10.1111/j.1750-3841.2010.01663.x

35. Lazarte, C. E., Carlsson, N.G., Almgren, A., Sandberg, A. S., Granfeldt, Y. (2015) Phytate, zinc, iron and calcium content of common Bolivian food, and implications for mineral bioavailability. Journal of Food Composition and Analysis. 39, 111-119 https://doi.org/10.1016/j.jfca.2014.11.015

36. Bhave, M., Morris, C.F. (2008). Molecular genetics of puroindolines and related genes: allelic diversity in wheat and other grasses. Plant Molecular Biology; 66(3),

https://doi.org/10.1007/s11103-007-9263-7

205-219

39. Egli, I., Davidsson, L., Juillerat, M.A., Barclay, D., Hurrell, R. (2003). Phytic acid degradation in complementary foods using phytase naturally occurring in whole grain cereals. Journal of Food Science, 68 (5), 1855-1859

https://doi.org/10.1111/j.1365-2621.2003.tb12342.x 40. Salem, H.B., Abdouli, H., Nefzaoui, A., ElMastouri, A., BenSalem, L. (2005). Nutritive behaviour, and growth of Barbine lambs fed on oldman saltbush (Atriplex nummularia L.) and supplemented or not with barley grains or spineless cactus (Opuntia ficus-intermis) pads. Small Ruminant Research, 59, 229-237

https://doi.org/10.1016/i.smallrumres.2005.05.010

41. Fardet, A. (2010). New hypotheses for the health protective mechanisms of whole grain cereals: what is beyond fiber? Nutrition Research Reviews, 23,65-134 https://doi.org/10.1017/S0954422410000041 
42. Moore, K.L., Zhao, F.J., Gritsch, C.S., Tosi, P., Hawkesford, M.J., McGrath, S.P., Shewry, P.R., Grovenor, C.R.M. (2012). Localisation of iron in wheat grain using high resolution secondary ion mass spectrometry. Journal of Cereal Science, 55, 183-187. https://doi.org/10.1016/i.jcs.2011.11.00

43. Brouns, F., Hemery, Y., Price, R., Anson, N.M. (2012). Wheat aleurone separation, composition, health aspects, and potential food use. Critical Reviews in Food Science and Nutrition, 52, 553-568 https://doi.org/10.1080/10408398.2011.589540

44. Chalamacharla, R.B., Harsha, K., Sheik, K.B., Viswanatha, C.K. (2018). Wheat bran- composition and nutritional quality: a review. Advances Biotechnology \& Microbiology, 9 (1), 555754 10.19080/AIBM.2018.09.555754

45. Fredlund, K., Isaksson, M., Rossander-Hulthén, L., Almgren, A., Sandberg, A.S. (2006). Absorption of zinc and retention of calcium: Dose-dependent inhibition by phytate. Journal of Trace Elements in Medicine and Biology. 20, 1, 49-57 https://doi.org/10.1016/j.jtemb.2006.01.003

46. Austin, R.B., Craufurd, P.Q. (1989). The Agrometeorology of rainfed barley-based farming systems. Proceedings of an International Symposium. Ed. M. Johns, G.Mathys and D. The Ecophysiology of barley Tunis 6-10 Mars; Rijks: 35-57

47. Salem, H.B., Nefzaoui, A., Ben Salem, L. (2004). Spliness cactus (Opuntia ficus indica $f$. Intermis) and oldman saltbush (Atriplex nummularia L.) As alternative supplements for growing Barbarine lambs given straw-based diets. Small Ruminant Research, 51, 65-73 https://doi.org/10.1016/S09214488(03)00186-X

48. Soylak, M., Tuzen, M., Narin, I., Sari, H. (2004). Comparison of microwave, dry and wet digestion procedures for the determination of trace metal. Journal of Food and Drug Analysis, 12(3), 254-258.

49. Peterson, C.M., Klepper, B., Rickman, R.W. (1989). Seed reserves and seedling developmen in winter wheat. Agronomy Journal, 81(2), 245-251

50. Bock, M.A. (2000). Minor Constituents of Cereals. Food Science and Technology-New York-Marcel Dekker; 479-504

51. Qiu, H., Nadaud, I., Ledoigt, G., PiquetPissaloux, A., Branlard, G. (2016). Interruption of magnesium supply at heading influenced proteome of peripheral layers and reduced grain dry weight of two wheat (Triticum aestivum L.) genotypes. Journal of Proteomics, 143, 83-92 https://doi.org/10.1016/j.jprot.2016.03.029

52. Bartnik, M., \& Jakubczyk, T. (1989). Chemical composition and the nutritive value of wheat bran. World review of nutrition and dietetics.

53. Sarpong, S. (2014). Traceability and supply chain complexity: confronting the issues and concerns. European Business Review, 26 (3), 271-284. https://doi.org/10.1108/EBR-09-2013-0113

54. Fraga, C.G. (2005). Relevance, essentiality and toxicity of trace elements in human health. Molecular Aspects of Medicine, 26, 235-244. https://doi.org/10.1016/j.mam.2005.07.013

55. Kaiser, C.R., Bowman, J.G.P., Surber, L.M.M., Blake, T.K., Borkowski,.J.J .(2004). Variation in apparent component digestibility of barley in the rat from the core collection of the USDA National Small Grains Collection. Animal Feed Science and Technology, $\quad 113 \quad$ (1-4), 97-112 https://doi.org/10.1016/i.anifeedsci.2003.11.008

56. Svihus, B., Gullord, M. (2002). Effect of chemical content and physical characteristics on nutritional value of wheat, barley and oats for poultry. Animal Feed Science and Technology, 102 (1-4), 71-92 https://doi.org/10.1016/S0377-8401(02)00254-7

57. Ragaee, S., El-Sayed, M., Abdel-Al Maher, N. (2006). Antioxydant activity and nutrient composition of selected cereals for food use. Food chemistry, 98 (1), 32-38 https://doi.org/10.1016/j.foodchem.2005.04.039 58. Fincher, G.B., Stone, B.A. (1986). Cell walls and their components in cereal grain technology. Advances in Cereal Science and Technology, 8, 207-295

59. Muir, J.G., Elaine, G.W., Keogh, J., Pizzey, C., Bird, A.R., Sharpe, K. (2004). Combining wheat bran with resistant starch has more beneficial effects on fecal indexes than does wheat bran alone. The American Journal of Clinical Nutrition, 79, 1020-1028 https://doi.org/10.1093/ajcn/79.6.1020

60. Kim, H., Stokes, K.S., Behall, K.M., Spears, K., Vinyard, B., Conway, J.M. (2009). Glucose and insulin responses to whole grain breakfasts varying in soluble fiber, $\beta$-glucan. European Journal of Nutrition, $48(3), \quad 170-175$ https://doi.org/10.1007/s00394-0090778-3

61. Biel, W., Bobko, K., Maciorowski, R. (2009). Chemicalcomposition and nutritive value of husked and naked oats grain. Journal of Cereal Science, 49, 413-418 https://doi.org/10.1016/j.jcs.2009.01.009

62. Wozniak, A., Soroka, M.S.T., Epniowska, A., Makarski, B. (2014). Chemical composition of spring barley (Hordeum vulgare L.) grain cultivated in various tillage systems. Journal of Elementology, 19(2), 597606. https://doi.org/10.5601/jelem.2014.19.2.438

63. Biel, W., Jaroszewska, A., Stankowski, S., Sadkiewicz, J., Bosko, P. (2015). Effects of genotype and weed control on the nutrient composition of winter spelt (Triticum aestivum ssp. Spelta L.) and common wheat (Triticum aestivum ssp. vulgare). Acta Agriculturae Scandinavica, Section B - Soil Plant Sci, 66(1), 27-35. https://doi.org/10.1080/09064710.2015.1062533

64. Alijošius, S., Švirmickas, G.J., Bliznikas, S., Gružauskas, R., Šašyte, V., RaceviciuteStupeliene, A., Kliševiciute, V., Daukšiene, A. (2016). Grain chemical composition of different varieties of winter cereals. Zemdirbyste, 103(3), 273280. https://doi.org/10.13080/z-a.2016.103.035

65. Biel, W., Maciorowski, R., Bobko, K., Jaskowska, I. (2011). Chemical composition and energy value of dwarf oats grain. Italian Journal of Food Science, 23(2), 180-187

66. Sykut-Domanska, E., Rzedzicki, Z., Nita, Z. (2013). Chemical Composition Variability of Naked and Husked Oat Grain (Avena sativa L.). Cereal Research Communications, 41(2), https://doi.org/10.1556/crc.2013.0007

67. Khan, M.S., Yu, X., Kikuchi, A., Asahina, M. (2009). Genetic engineering of glycine betaine biosynthesis to enhance abiotic stress tolerance in 
plants. Plant Biotechnology, 26, 125-13 https://doi.org/10.5511/plantbiotechnology.26.125

68. Frances, M.D., William, J.H., William, H.V., Charlene, T., Kerry, M.K., Okkyung, K.C., Susan, B.A. (2006). Protein accumulation and composition in wheat grains: effects of mineral nutrients and High temperature. European Journal of Agronomy, 25(2), 96-107 https://doi.org/10.1016/j.eja.2006.04.003
69. Raza, S.H., Athar, H.R., Ashraf, M., Hameed, A. (2007). Glycine betaine-induced modulation of antioxidant enzymes activities and ion accumulation in two wheat cultivars differing in salt tolerance. Environmental and Experimental Botany, 60(3), 368376 https://doi.org/10.1016/i.envexpbot.2006.12.009 